\title{
Effects of Dietary Crude Protein on Performance and Nitrogen Economy of Broilers
}

\author{
Malomo G. A. ${ }^{1}$, Bolu S. A. ${ }^{2} \&$ Olutade S. G. ${ }^{1}$ \\ ${ }^{1}$ Coordination of Technical Research Programme, Agricultural Research Council of Nigeria, Abuja, Nigeria \\ ${ }^{2}$ Animal Production Department, University of Ilorin, Ilorin, Nigeria \\ Correspondence: Bolu S. A., Animal Production Department, University of Ilorin, Ilorin, Nigeria. Tel: \\ 234-806-024-0049. E-mail: bolusao2002@yahoo.co.uk
}

Received: March 13, 2013 Accepted: April 16, 2013 Online Published: April 28, 2013

doi:10.5539/sar.v2n3p52

URL: http://dx.doi.org/10.5539/sar.v2n3p52

\begin{abstract}
This study assessed the effects of dietary crude protein on performance and nitrogen economy of broilers. Chicks were allotted to $22,20,18$ and $16 \%$ crude protein corn-soy diets in a completely randomized design for forty-two days. Several essential amino acids were observed to be deficient compared to recommendations for broiler chicks as the dietary crude protein level reduced. Feed intake, weight gain, feed to gain ratio, faecal nitrogen, nitrogen retention, anthropogenic potential and dressing percentage were influenced $(\mathrm{P}<0.05)$ by the dietary treatments. However, mortality was not significantly different $(\mathrm{P}>0.05)$. Feed intake, weight gain, nitrogen intake and output were significantly $(\mathrm{P}<0.05)$ depressed as the $\mathrm{CP}$ level reduced. However, the best $(\mathrm{P}$ $<0.05)$ nitrogen retention and percentage faecal nitrogen was recorded for broilers fed $20 \%$ crude protein diet. Serum total protein, albumin, uric acid, creatinine and glucose were affected $(\mathrm{P}<0.05)$ across treatments. It was concluded that there is a limit to which dietary crude protein of broilers could be reduced without any detrimental effects on the performance and nitrogen economy of the birds, even when the requirements for methionine and lysine has been met, as several other amino acids could be limiting. Consequently, to achieve significant improvement in nitrogen economy and reduction in amount of faecal nitrogen, $20 \%$ crude protein diets could be fed to broilers. However, there may be need to further manipulate the amino acid profile of the diet so as to improve its performance to be at par with higher crude protein diets.
\end{abstract}

Keywords: broiler chicks, nitrogen economy, faecal nitrogen, performance

\section{Introduction}

Air emissions, especially, from intensive poultry production and manure management are major contributors to the release of various forms of nitrogenous compounds. Thus, taking measures that enhance the emission profiles from poultry production operations through reduction of excessive nitrogen emissions could help mitigate air pollution and contributions to climate change. Altering feeding practices to achieve improved nutrient use efficiency in animals could result in significant reduction in amounts of ammonia released during production and nitrous oxide released from animal manure during storage (Kulling et al., 2003; Pattey et al., 2005; Hindrichsen et al., 2006). Consequently, avoiding over-supply of protein and amino acid concentration in broilers' feed could help reduce nitrogen release in litters (Soliva et al., 2006; Monteny et al., 2006) and the amount of faecal nitrogen ultimately available for denitrification.

Essentially, dietary requirements for protein are requirements for amino acids. Therefore, dietary formulations based on the amino acid requirements of birds rather than $\mathrm{CP}$ can minimize $\mathrm{N}$ excretion by simply reducing total dietary $\mathrm{N}$ intake (NRC, 1994). Adequate intake of dietary amino acids is required by birds to achieve optimum performance measured in terms of growth, feed conversion ratio (FCR) and carcass quality (Bryden \& Li, 2004). Dietary supplementation of amino acids can be used to reduce dietary CP content and $\mathrm{N}$ excretion. Waldroup et al. (1976) reported that minimizing excess dietary amino acids resulted in improved performance of broiler chicks. Corzo et al. (2004) also demonstrated improvements in nitrogen utilization in terms of plasma uric acid, dietary nitrogen intake, excretion and retention without deleterious consequences on live performance of chicks when low crude protein diet was fed to broilers. The objective of the study is to assess the effects of reducing dietary protein level by up to $7 \%$ of NRC (1994) recommended value $(23.5 \%)$ on performance and nitrogen economy of broilers. 


\section{Materials and Methods}

One hundred and sixty eight (168) day old and mixed sex Arbor Acre Plus broilers chicks were purchased and randomly allocated to twelve pens (at a density of $0.1 \mathrm{~m}^{2} / \mathrm{bird}$ ). Birds were given water and feed ad libitum (Table 1) for a study period of 6 weeks. Different crude protein levels diets were the treatments in this study. The levels of crude proteins were 22.0, 20.0, 18.0 and 16.0\%. Proximate compositions of feed and faecal samples were carried out using the methods of AOAC (1990), while amino acid assay of the feed samples was carried out according to Spackman et al. (1958). All the diets were formulated to meet NRC (1994) recommendation for methionine and lysine, however, no attempt was made to adjust the levels after analysis. The proximate composition of the diets as analyzed is shown in Table 1. Birds were randomly allocated to these treatments in three units (replicates) of fourteen (14) birds each.

Birds were vaccinated against Newcastle disease at 1 week and 3 weeks of age as well as Infectious Bursa Disease at 2 weeks of age. The study was conducted for 6 weeks. Data were collected daily on feed intake and weight gain. Feed: gain was computed from the data of daily feed intake as a ratio of weight gain. At the end of the third week of the study, a nutrient retention study was conducted in metabolism cages. Feed was weighed and given to birds and faecal samples collected over a period of 72 hours employing total collection method. Faecal samples were oven-dried, ground and analyzed for Nitrogen. Anthropogenic Potential (AP) of each treated was calculated as:

$$
\text { Anthropogenic propensity } \left.=2\left(\mathrm{y}_{1} / \mathrm{y}_{2}\right) / \mathrm{y}_{3}\right) \times \mathrm{K}
$$

Where:

$\mathrm{y}_{1}=\%$ faecal nitrogen; $\mathrm{y}_{2}=$ mass of nitrogen, and $\mathrm{K}=\mathrm{GWP}$ of nitrous oxide (Bolu et al., 2011)

Table 1. Composition of experimental diets

\begin{tabular}{ccccc}
\hline Ingredients & $22 \%$ & $20 \%$ & $18 \%$ & $16 \%$ \\
\hline Maize & 52.6 & 58.3 & 60 & 63 \\
SBM & 31.3 & 25.6 & 23.9 & 17.6 \\
WB & 6.2 & 6.2 & 9.0 & 12.3 \\
Fish Meal & 4.0 & 4.0 & 1.0 & 1.0 \\
Palm oil & 3.0 & 3.0 & 3.0 & 3.0 \\
Bone Meal & 0.3 & 0.3 & 0.3 & 0.3 \\
Lysine & 0.1 & 0.1 & 0.2 & 0.2 \\
Methionine & 0.1 & 0.1 & 0.2 & 0.2 \\
Salt & 0.25 & 0.25 & 0.25 & 0.25 \\
Premix & 0.25 & 0.25 & 0.25 & 0.25 \\
Oyster Shell & 1.9 & 1.9 & 1.9 & 1.9 \\
\hline Total & 100.0 & 100 & 100 & 100 \\
\hline & Composition of Diets on as analyzed basis & \\
\hline Crude Protein & 21.88 & 19.99 & 18.07 & 16.01 \\
Crude Fibre & 4.86 & 5.78 & 6.04 & 5.20 \\
Ash & 5.29 & 6.02 & 6.64 & 4.76 \\
Crude Fat & 7.50 & 7.35 & 7.11 & 6.61 \\
DM & 91.99 & 91.19 & 90.21 & 91.00 \\
\hline
\end{tabular}

At the end of the study, three birds per treatment were starved for $12 \mathrm{~h}$ prior to slaughtering by head decapitation. After evisceration of the carcass, a carcass characteristics assessment was conducted. Also, blood samples were taken from 3 birds from each treatment into bijou bottles containing EDTA (anticoagulant). PCV, haemoglobin concentration, total RBC, were evaluated according to Dacie and Lewis (1997). Serological samples were taken from blood (without anticoagulant), centrifuged at $4000 \mathrm{rpm}$ for 3 minutes and supernatant sera harvested in bijou bottles for the determination of specific serum biochemical indices. Enzyme assay for serum aspartate amino transferase (AST, EC 2.6.1.1) and alanine amino transferase (ALT, EC 2.6.1.2) were determined by the colorimetric method of Reitman and Frankel (1957), while alkaline phosphate (AP < EC 3.1.1.3) was determined 
by the kinetic method of Frajola et al. (1965). Response criteria were subjected to analysis of variance and treatment means separated by Duncan Multiple Range Test using the SAS statistical analytical package (SAS, 1985).

\section{Results and Discussion}

Amino acid profiles of the experimental diets are presented in Table 2. Although, methionine and lysine are the most critical amino acids in a corn and soybean meal (CSM)-based broiler diets, however, at some reduced dietary protein levels, amino acids such as; arginine, threonine, valine, proline, leucine, becomes limiting, as observed in the present study. The trends of amino acids levels present in the diets are consistent with the findings of Corzo et al. (2004) who reported the need to add certain amounts of non-essential nitrogen to low crude protein diets to enable chicks perform as well as those on high crude protein diets.

Feed intake, weight gain, feed: gain, faecal nitrogen, nitrogen retention, anthropogenic potential and dressing percentage were influenced $(\mathrm{P}<0.05)$ by the dietary treatments (Table 3$)$. However, mortality was not significantly different $(\mathrm{P}>0.05)$. Feed intake, weight gain, nitrogen intake and output were depressed as the CP level reduced. Although, broilers fed the $22 \% \mathrm{CP}$ diets had the highest feed intake and weight gain, they did not differ in feed: gain from birds on $20 \% \mathrm{CP}$ diet. On the other hand, birds fed $20 \% \mathrm{CP}$ diet had the most superior $(\mathrm{P}<0.05)$ nitrogen retention and faecal nitrogen, while AP was lowest $(\mathrm{P}<0.05)$ for broilers fed 18 and $16 \% \mathrm{CP}$ diets, largely due to very low faecal output. This implied reduced risk for the environment due to significant reduction in the amount of faecal $\mathrm{N}$ available for conversion to nitrous oxide and eventual release into the atmosphere. This is because as faecal nitrogen decreases, nitrous oxide produced from denitrified faecesare expected to reduce (Misselbrook, 1998; Eberherd, 2007).

Table 2. Amino acid profile of experimental diets (\%)

\begin{tabular}{cccccc}
\hline \multirow{2}{*}{ Parameter } & \multicolumn{5}{c}{ Diets $(\% \mathrm{CP})$} \\
\cline { 2 - 6 } & 22 & 20 & 18 & 16 & NRC1994 \\
\hline Lysine & 1.01 & 0.91 & 0.76 & 0.55 & 1.10 \\
Histidine & 0.55 & 0.47 & 0.39 & 0.32 & 0.35 \\
Arginine & 1.21 & 1.06 & 0.89 & 0.75 & 1.25 \\
Aspartic acid & 1.96 & 1.73 & 1.47 & 1.47 & NA \\
Threonine & 0.71 & 0.61 & 0.51 & 0.45 & 0.8 \\
Serine & 0.72 & 0.63 & 0.58 & 0.47 & NA \\
Glutamic acid & 3.04 & 2.70 & 2.33 & 2.07 & NA \\
Proline & 0.75 & 0.68 & 0.56 & 0.48 & 0.60 \\
Glycine & 0.92 & 0.78 & 0.65 & 0.53 & NA \\
Alanine & 0.99 & 0.90 & 0.73 & 0.63 & NA \\
Cysteine & 0.26 & 0.21 & 0.19 & 0.16 & NA \\
Valine & 0.89 & 0.80 & 0.65 & 0.52 & 0.9 \\
Methionine & 0.51 & 0.46 & 0.38 & 0.30 & 0.5 \\
Isoleucine & 0.77 & 0.69 & 0.59 & 0.51 & 0.8 \\
Leucine & 1.79 & 1.61 & 1.36 & 1.16 & 1.2 \\
Tyrosine & 0.70 & 0.60 & 0.50 & 0.44 & NA \\
Phenylalanine & 1.13 & 0.99 & 0.82 & 0.67 & 0.72 \\
\hline
\end{tabular}

NA: Not available.

However, at dietary CP levels of 18 and $16 \%$, performance of broilers suffered and nitrogen economy became less efficient, when compared with birds fed 20 and $22 \%$ CP diets. The observed decline in body weight gains of broilers as the dietary crude protein decreased could be attributed to low feed intake resulting in inadequate consumption of some essential amino acids. Undersupply of amino acids such as methionine + cytine, lysine, threonine and arginine may result in serious consequences including increased FCR, reduced breast muscle and reduced carcass quality in the birds that feed on them (NRC, 1994). Fisher and Shapiro (1961) reported that poor body weight gain in birds fed low protein diets which are deficient in tryptophan and lysine or methionine are 
fundamentally caused by a decrease in feed intakes rather than alteration in effectiveness of first limiting amino acids. Dressing percent showed direct relationship with dietary crude protein levels, which indicates that feeding low crude protein diets affected carcass yield in broilers (Bregendahl et al., 2002). Consequently, there is a limit to which dietary $\mathrm{CP}$ of broilers could be reduced without any detrimental effects on the performance of the birds, even when the requirement for methionine and lysine has been balanced.

Table 3. Effects of dietary protein level on performance, N-retention and anthropogenic potentials of broilers

\begin{tabular}{|c|c|c|c|c|c|}
\hline \multirow{2}{*}{ Parameter } & \multicolumn{4}{|c|}{ Diets $(\% \mathrm{CP})$} & \multirow{2}{*}{ SEM } \\
\hline & 22 & 20 & 18 & 16 & \\
\hline Feed intake $(\mathrm{g} / \mathrm{b} / \mathrm{d})$ & $50.06^{\mathrm{a}}$ & $46.92^{b}$ & $38.10^{\mathrm{c}}$ & $33.46^{\mathrm{d}}$ & 0.81 \\
\hline Weight gain $(\mathrm{g} / \mathrm{b} / \mathrm{d})$ & $25.38^{\mathrm{a}}$ & $23.66^{\mathrm{b}}$ & $10.72^{\mathrm{c}}$ & $10.55^{\mathrm{c}}$ & 0.52 \\
\hline Feed Conversion Ratio & $1.97^{\mathrm{a}}$ & $1.99^{\mathrm{a}}$ & $3.57^{\mathrm{c}}$ & $3.18^{\mathrm{b}}$ & 0.13 \\
\hline Mortality & 0 & 2 & 1 & 1 & 0.03 \\
\hline Dressing percentage & $72.18^{\mathrm{a}}$ & $71.47^{\mathrm{a}}$ & $68.11^{\mathrm{ab}}$ & $64.63^{\mathrm{b}}$ & 1.32 \\
\hline Nitrogen intake $(g / b / d)$ & $3.44^{\mathrm{a}}$ & $2.66^{\mathrm{b}}$ & $0.95^{\mathrm{c}}$ & $0.85^{\mathrm{d}}$ & 0.03 \\
\hline Nitrogen output $(\mathrm{g} / \mathrm{b} / \mathrm{d})$ & $0.61^{\mathrm{a}}$ & $0.31^{\mathrm{b}}$ & $0.22^{\mathrm{c}}$ & $0.21^{\mathrm{c}}$ & 0.01 \\
\hline Faecal Nitrogen (\%) & $1.37^{\mathrm{b}}$ & $1.27^{\mathrm{c}}$ & $1.47^{\mathrm{a}}$ & $1.37^{\mathrm{b}}$ & 0.01 \\
\hline Nitrogen retention (\%) & $82.32^{\mathrm{b}}$ & $88.49^{\mathrm{a}}$ & $76.50^{\mathrm{c}}$ & $75.31^{\mathrm{d}}$ & 0.34 \\
\hline Anthropogenic Potential & $1.41^{\mathrm{a}}$ & $0.88^{\mathrm{b}}$ & $0.69^{\mathrm{c}}$ & $0.65^{\mathrm{c}}$ & 0.02 \\
\hline
\end{tabular}

Treatments having same letter superscript along the row are not significantly different.

Haematological parameters and serum biochemistry of birds offered the various experimental diets are presented in Tables 4 and 5, respectively. Packed Cell Volume (PCV), Red Blood Cells (RBC) and White Blood Cells (WBC) counts showed significant $(\mathrm{P}<0.05)$ decreasing treatment effects (Table 4) and were directly proportional to dietary crude protein levels. This finding is in agreement with the reports of Jean (1993) and Talebi et al. (2005) that diet is one of the factors influencing RBC and WBC in the same individuals. However, haemoglobin, neutrophils and lymphocytes values did not differ $(\mathrm{P}>0.05)$ across treatments.

Table 4. Effects of graded levels of dietary protein on haematology of broilers

\begin{tabular}{llllll}
\hline Parameter & \multicolumn{4}{c}{ Diets (\%CP) } & \multirow{2}{*}{ SEM } \\
\cline { 2 - 4 } & 22 & 20 & 18 & 16 & \\
\hline Packed Cell Volume (\%) & $38.00^{\mathrm{a}}$ & $36.33^{\mathrm{a}}$ & $31.00^{\mathrm{b}}$ & $30.33^{\mathrm{b}}$ & 1.34 \\
White Blood Cells (x10 $/ \mathrm{L})$ & $10.40^{\mathrm{a}}$ & $9.80^{\mathrm{ab}}$ & $9.33^{\mathrm{b}}$ & $9.23^{\mathrm{b}}$ & 0.28 \\
Red Blood Cells (x10 $12 \mathrm{~L})$ & $11.63^{\mathrm{a}}$ & $10.40^{\mathrm{ab}}$ & $9.77^{\mathrm{b}}$ & $9.47^{\mathrm{b}}$ & 0.48 \\
Haemoglobin (g/dl) & 8.07 & 7.23 & 7.03 & 6.80 & 0.46 \\
Neutrophils (\%) & 65.67 & 69.33 & 65.33 & 70.67 & 2.62 \\
Lymphocytes (\%) & 28.67 & 28.67 & 30.67 & 26.67 & 3.48 \\
\hline
\end{tabular}

Treatments having similar letter superscript along the row are not significantly different.

The levels of serum proteins, albumin, uric acid, creatinine and glucose varied significantly $(\mathrm{P}<0.05)$ across treatments. However, while the relationship of dietary crude protein was observed to be direct with the serum protein and albumin levels; and indirect with uric acid and creatinine, no particular trends were observed for glucose (Table 5). The significant $(\mathrm{P}<0.05)$ relative increase in serum uric acid as the dietary protein level decreased suggests reduced bio-availability of the individual or a collection protein source in the diets. Blood uric acid is an inferential criterion for assessing the bio-availability of protein sources for broilers and such dietary protein sources with higher biological values cause a lower uric acid concentration in the blood serum compared with those with lower biological values (Hevia \& Clifford, 1977). 
Table 5. Effects of graded levels of dietary protein on serum biochemistry of broilers

\begin{tabular}{llllll}
\hline Parameter & \multicolumn{4}{c}{ Diets (\%CP) } & SEM \\
\cline { 2 - 5 } & 22 & 20 & 18 & 16 & \\
\hline Serum protein (mmol/L) & $79.67^{\mathrm{a}}$ & $72.33^{\mathrm{a}}$ & $62.33^{\mathrm{b}}$ & $61.67^{\mathrm{b}}$ & 4.81 \\
Albumin (mmol/L) & $49.67^{\mathrm{a}}$ & $39.67^{\mathrm{ab}}$ & $32.00^{\mathrm{b}}$ & $31.33^{\mathrm{b}}$ & 4.01 \\
Uric acid (mmol/L) & $6.90^{\mathrm{c}}$ & $8.20^{\mathrm{bc}}$ & $8.97^{\mathrm{ab}}$ & $9.97^{\mathrm{a}}$ & 0.46 \\
Creatinine (mmol/L) & $1.00^{\mathrm{b}}$ & $1.81^{\mathrm{a}}$ & $1.90^{\mathrm{a}}$ & $2.04^{\mathrm{a}}$ & 0.09 \\
Glucose (mmol/L) & $1.90^{\mathrm{b}}$ & $2.53^{\mathrm{a}}$ & $1.63^{\mathrm{b}}$ & $1.30^{\mathrm{b}}$ & 0.19
\end{tabular}

Treatments having similar letter superscript along the row are not significantly different.

\section{Conclusion}

Reducing dietary crude protein for broilers showed great promises as a tool for reducing the amount of faecal nitrogen available for denitrification. However, there is a limit to which dietary crude protein of broilers could be reduced without any detrimental effects on the performance and nitrogen economy of the birds, even when the requirement for methionine and lysine has been met. The results of this study showed that to achieve significant improvement in nitrogen economy and reduction in amount of faecal nitrogen, $20 \%$ crude protein diets should be fed to broilers. However, there may be need to further manipulate the amino acid profile of the diet so as to improve its performance to higher crude protein diets.

\section{References}

Association of Official Analytical Chemists. (1990). Official methods of analysis (15th ed.), Washington DC.

Bolu, S. A., Ojo, V., Malomo, G. A., Oladele, P. O., \& Olonijolu, T. O. (2011). Dietary levels of protein and sustainable broiler production. Journal of Applied Agricultural Research, 3, 133-139.

Bregendahl, K. J. L., Sell, J. L., \& Zimmerman, D. R. (2002). Effect of low-protein diets on growth performance and body composition of broiler chicks. Poultry Science, 81, 1156-1167.

Bryden, W. L., \& Li, X. (2004). Utilisation of digestible amino acids by broilers. RIRDC Publication No. 04/030. Rural Industries Research and Development Corporation.

Corzo, A., McDaniel, C. D., Kidd, M. T., Miller, E. R., Boren, B. B., \& Fancher, B. I. (2004). Impact of dietary amino acids concentration on growth, carcass yield and uniformity of broilers. Australian Journal of Agricultural Research, 55, 1133-1138. http://dx.doi.org/10.1071/AR04122

Dacie, J. W., \& Lewis, S. M. (1997). Practical haematology (5th ed.), (pp. 21-68). Longman group Ltd.

Eberhard, J. (2007). Quantify Airborne Emissions from Buildings, stores and Land Application: greenhouse gas Emissions from Animal Husbandry. Retrieved from http://www.agriculture.de/acms1/conf6/ws4quant.htm

Fisher, H., \& Shapiro, R. (1961). Amino acid imbalance: Rations low in tryptophan, methionine or lysine and the efficiency of utilization of nitrogen in imbalanced rations. Journal of Nutrition, 62, 349.

Frajola, W. J., William, R. D., \& Austin, R. A. (1965). The kinetic spectro-photometric assay for serum alkaline phsphatase. Am, J. Clin. Path, 43, 261-264.

Hevia, P., \& Clifford, J. (1977). Protein intake, uric acid metabolism and protein efficiency ratio in growing chicks. Journal of Nutrition, 107(6), 959-964.

Hindrichsen, I. K., Wettstein, H. R., Machmüller, A., \& Kreuzer, M. (2006). Methane emission, nutrient degradation and nitrogen turnover in dairy cows and their slurry at different production scenarios with and without concentrate supplementation. Agriculture, Ecosystems and Environment, 113, 150-161. http://dx.doi.org/10.1016/j.agee.2005.09.004

Jean, P. (1993). Animal production in the tropics and sub-tropics (1st ed.). (pp. 71-73). MacMillan CTA.

Külling, D. R., Menzi, H., Sutter, F., Lischer, P., \& Kreuzer, M. (2003). Ammonia, nitrous oxide and methane emissions from differently stored dairy manure derived from grass- and hay-based rations. Nutrient Cycling in Agroecosystems, 65, 13-22. http://dx.doi.org/10.1023/A:1021857122265

Misselbrook, T. (1998). Inventories of Ammonium and Greenhouse Gases from U.K. 
Monteny, G. J., Bannink, A., \& Chadwick, D. (2006). Greenhouse gas abatement strategies for animal husbandry. Agriculture, Ecosystems and Environment, 112, 163-170. http://dx.doi.org/10.1016/j.agee.2005.08.015

National Research Council. (1994). Nutrient requirements of poultry (9th ed.). Washington, D. C.: National Academy Press.

Pattey, E., Trzcinski, M. K., \& Desjardins, R. L. (2005). Quantifying the reduction of greenhouse gas emissions as a result of composting dairy and beef cattle manure. Nutrient Cycling in Agroecosystems, 72, 173-187. http://dx.doi.org/10.1007/s10705-005-1268-5

Reitman, S., \& Frankel, A. (1957). Method of Transaminase determination in serum. J. Clin. Path., $28,56-59$.

SAS Institute. (1985). SAS users guide statistics. Carry, NC. SAS Institute.

Soliva, C. R., Takahashi, J., \& Kreuzer, M. (eds.) (2006). Greenhouse Gases and Animal Agriculture: An Update. International Congress Series.The Netherlands: Elsevier.

Spackman, D. H., Stein, E. H., \& Moore, S. (1958). Automatic recording apparatus for use in the chromatography of amino acids. Analytical Chemistry, 30, 1191. http://dx.doi.org/10.1021/ac60139a006

Talebi, A., Asri-Rezaer, S., Rozeh-Chai, R.,\& Sahraei, R. (2005). Comparative studies on haematology values of broiler strains (Ross, Cobb, Arbor-Acre and Arian). Int. Journal of Poultry Science, 4(8), 573-579. http://dx.doi.org/10.3923/ijps.2005.573.579

Waldroup, P. W., Mitchell, R., Payne, J. R., \& Hazen, K. R. (1976). Performance of chicks fed diets formulated to minimize excess levels of essential amino acids. Poultry Science, 55, 1225. http://dx.doi.org/10.3382/ps.0550243

Waldroup, P. W. (2000). Feeding programs for broilers: The challenge of low protein diets. In Proceedings of 47th Maryland Nutrition Conference, University of Maryland, College Park, MD., pp. 119-134. 